\title{
The Influence of Teacher Education Level and Working Period on Teacher Pedagogic Competence
}

\author{
Maryani \\ SD Negeri 11 Ogan Komering Ulu \\ e-mail: maryanisdn11@gmail.com \\ Yasir Arafat \\ Universitas PGRI Palembang \\ e-mail: yasirarafat@ univpgri-palembang.ac.id \\ Andi Arif Setiawan \\ Universitas PGRI Palembang \\ e-mail: andiarifsetiawan@univpgri-palembang.ac.id \\ Article History: Received on 11 November 2021, Revised on 20 December 2021 \\ Published on 10 January 2022
}

\begin{abstract}
The purpose of this quantitative study is to investigate the effect of both partial and simultaneous differences in education level and tenure of service on teachers' pedagogical competence. A questionnaire was used to collect data for this study, and SPSS was used to analyze the data statistically. The study's findings suggest that the level of education and years of service have a partial or simultaneous influence on a teacher's pedagogical competence. This study makes recommendations for increasing teachers' educational levels in order to improve their pedagogical competence.
\end{abstract}

Keywords: Education Level, Frequency of Working, Teacher Competency

\section{A. Introduction}

Education, as a human endeavor, is the best aspect and result of culture that any generation of humans can provide for the benefit of the younger generation in order for them to continue their life and way of life in a socio-cultural context. Education is a basic human need that must be met throughout one's life. It is absolutely impossible for a human group to live and develop in accordance with their aspirations to progress, prosper, and be happy according to their worldview (Firdaus, 2014). Education is critical to achieving national development. Humans will be born with the potential and talents to contribute to the country as a result of education. In order for human beings to be born who contribute to the nation's development. As a result, the educational process requires special attention (Pramono, 2012).

Education is the process of preparing people to adapt to environmental changes. Education is important in national development because it is one method of developing quality human resources to achieve national development goals. The younger generation is the nation's future generation. The younger generation is largely responsible for the advancement of the nation's progress. Education for the next generation is expected to aid in the achievement of national development objectives. The educated and accomplished young generation is expected to lead 
this country into global competition, particularly in education. There are two educational paths: formal education and non-formal education (Prihatini et al, 2021).

Formal education is obtained through educational institutions, specifically schools, and is a tiered education that progresses from the lowest to the highest level of education. While nonformal education is a type of training that takes place outside of formal education, such as courses. Education serves three functions: it prepares the whole person, it prepares the workforce, it prepares good citizens, and it prepares agents of social reform. Secondary education is held with the goal of continuing education, preparing citizens for the future learning process, and preparing graduates to be good citizens. Senior High School and Vocational High School are the two levels of secondary education. It is possible to conclude that education is intended to form a complete human being, a mature, faithful, and devoted individual who is independent, knowledgeable, and responsible. Education also shapes people into social reform agents, preparing them to face, adapt to, and anticipate the future.

Because education is a never-ending conversation, it is not surprising that the general public's awareness of the importance of education is gradually increasing. The world of education includes both students and teachers as educators, as well as the interaction between the two. This interaction is a place for knowledge and skill development. In a learning process, the interaction between the two takes place in a specific context (Astuti et al, 2020).

Education is the process of preparing people to adapt to environmental changes. Education is important in national development because it is one method of developing quality human resources to achieve national development goals. The younger generation is the nation's future generation. The younger generation is largely responsible for the advancement of the nation's progress. Education for the next generation is expected to aid in the achievement of national development objectives. The educated and accomplished young generation is expected to lead this country into global competition, particularly in education.

Education is the primary means of advancing the nation's life, and it must be managed systematically and consistently over time in accordance with the nation's living environment. Education is an absolute necessity for a developing nation such as the Indonesian nation today, and it must be developed in accordance with the demands of development one step at a time. Education that is managed in an orderly, orderly, effective and efficient manner will accelerate the process of civilizing the nation (Firdaus, 2014).

Teachers' roles and responsibilities in the world of education are critical. In addition to transferring knowledge to students, teachers are expected to provide character education and to set a good example for their students. Article 1 paragraph 1 of Law Number 14 of 2005 concerning teachers and lecturers defines a teacher as "professional educators with the primary task of educating, teaching, guiding, directing, training, assessing, and evaluating students in early childhood education pathways." "Formal education, primary education, and secondary education."

Education is also inextricably linked to a teacher's level of education and tenure. Every teacher has the ability to improve their competence in general, because professional competence is influenced by personal factors unique to each teacher. According to Fitria et al. (2019), one of them has academic credentials. Having academic credentials Because education can shape a person's mindset and increase knowledge, it can have an impact on teacher performance. 
Volume 2 (3) 2021

E-ISSN: 2723-6919 P-ISSN: 2746-0827

Differences in education can lead to differences in how people think and act. The level of knowledge possessed by a teacher has a significant impact on his ability to carry out his duties as an educator in charge of transferring knowledge to students. Furthermore, a well-educated person will think before acting. This has an impact on how a teacher carries out his mandate and maintains his performance (Riyany et al, 2021; Firman et al, 2021).

Furthermore, one of the characteristics of a professional job, according to Jasin, is a high level of education. This is due to the fact that the level of specialist education requires a person to carry out his work with full responsibility, independence in decision making, proficiency, and skill in doing his job (Saudagar and Idrus, 2009). Educational science, as the spirit of the educational profession's development, investigates and provides an understanding of how the duties and behavior of professional educators can create educational and enjoyable learning services (Saudagar and Idrus, 2009). According to Krisdiana and Marimin (2014), educational level is a long-term process that employs a systematic and organized procedure in which the managerial workforce learns conceptual and theoretical knowledge for general purposes.

According to Law No. 14 of 2005 Concerning Teachers and Lecturers, professional teachers must have four competencies in addition to a minimum academic qualification of S1, namely pedagogic competence, social competence, professional competence, and personality competence. Competence denotes the possession of the knowledge, skills, and abilities required for specific positions. Competence can also be defined as knowledge, skills, and fundamental values that are reflected in one's way of thinking and acting. Competence can also refer to the ability to perform tasks obtained through education or training.

The ability to manage student learning is referred to as pedagogic competence. Teachers must have this pedagogical competence in order to manage learning, which includes the ability to understand students, design and implement learning, evaluate learning outcomes, and develop students to realize their full potential. Pedagogic competence is the science of children's education whose scope is limited to educative interactions between educators and students, or it is a set of teacher abilities related to the science and art of teaching students (Muchith, 2008).

A teacher's pedagogical ability is not easy to come by, because the teacher's quality must be above average. This quality can be seen from the intellectual aspect, which includes aspects of (a) logic as cognitive development, which includes intellectual abilities regarding the environment, which consist of six kinds arranged hierarchically from simple to complex, namely knowledge, understanding, application, analysis, synthesis, and assessment; and (b) ethics as an affective developer, which includes the emotional ability to experience and live something, which includes five kinds of emotional abilities a) knowledge, understanding, application, analysis, synthesis, and assessment (Sadulloh, 2010).

Competent teachers will carry out teaching and learning tasks in class with enthusiasm, fun, and meaning, and students will always learn something new every time they enter the classroom to learn. Because the teacher is competent, students will never be bored while learning in class. Finally, competent teachers will produce students who study hard because they enjoy the learning process and recognize the value of education in the future. If teachers are incompetent, their students will produce a generation of low-quality workers (Musfah, 2011). Not only is it difficult for them to compete, but it is also difficult for them to find work, so it is not impossible that they will become a social burden for the community and this country in the future. As a result, a teacher's competence is critical for both the teacher and his students. 
A teacher must be competent because he or she has an obligation to educate the nation's children not only physically but also emotionally. The teacher's job is to educate rather than just teach, because educating has a broader and more complex meaning than teaching. A teacher must have good pedagogical competence in order for the teaching and learning process to be properly created and student achievement to be properly achieved.

The most fundamental activities in the educational process are teaching and learning. The success or failure of educational goals is heavily dependent on how teaching and learning activities are carried out. The success of education can be determined by the outcomes or student achievement. Tohirin defines learning achievement as "what students have achieved after engaging in learning activities".

The more effective the teaching and learning activities, the higher the student achievement. To determine the success or failure of teaching and learning activities over time, the school administers evaluations ranging from daily tests, block tests, midterm exams, semester end exams, and national exams (UN), so that teachers, students, schools, and other parties involved can learn about their accomplishments and the extent to which their learning effectiveness has been achieved.

The issue of teacher competence remains a serious concern, as evidenced by the fact that, since the implementation of the KBK in schools and madrasas, the teacher competency test has only tested cognitive competence, leaving out competencies from the affective, psychomotor, and value domains (Sudarminta, 2001). It is ironic that students are led to learning demands that must be in accordance with the KBK, but teachers have not been prepared for the content of the KBK itself, namely as the primary driving force of the curriculum.

According to Sudarminta (2001), the following symptoms indicate poor teacher quality. (1) a lack of mastery of the material being taught; (2) a disparity between the field of study that the teacher learns and what is actually in the field being taught; (3) less effective teaching methods; (4) the teacher's lack of authority in front of students; (5) a lack of motivation and dedication to becoming a true educator; an increasing number of people who happen to be teachers but do not truly become teachers; and (6) a lack of emotional maturity, independent thinking, and a firm attitude in quitting. Most teachers continue to function as teachers rather than educators in their interactions with students; (7) the lower intellectual level of student teacher candidates admitted to the LPTK (Institution for the Procurement of Educational Personnel) compared to those admitted to the university.

Aprinda et al, (2020) stated that their research results have an effect on the supervision of school principals and the work motivation of teachers together on teacher performance in State Junior High Schools in West Prabumulih District. According to the findings of their study, the principal carried out the academic supervision process in four stages: 1) planning of academic supervision activities; 2) implementation of academic supervision; 3) providing feedback on the results of academic supervision; and 4) following up on the results of academic supervision. The assessment tools are in the form of supervision instruments, which include: 1) instruments for administrative assessment of learning devices; 2) instruments for RPP assessment; 3) instruments for assessing learning implementation; 4) Instrument for assessing learning evaluation; instruments for follow-up; instrument for evaluating teacher performance. The outcomes of academic supervision have the potential to improve teacher performance at SD Negeri 16 Gelumbang. According to Israwanti et al. (2018), the findings of their study showed 
Volume 2 (3) 2021

E-ISSN: 2723-6919 P-ISSN: 2746-0827

that teaching motivation had a positive and significant effect on teacher performance. Professional competence has a significant and positive impact on teacher performance. At SMK Negeri 4 Soppeng, the level of education has a positive and significant effect on teacher performance. At SMK Negeri 4 Soppeng, teaching motivation, professional competence, and level of education all have a positive and significant effect on teacher performance.

According to Arino (2017), the findings of the study revealed that the level of education, tenure, and work motivation all had a significant impact on the performance of village officials. According to the findings of the study, Firdaus (2014), the level of teacher education and training influences teacher professionalism. In their study, Triyanto and Handayani (2016) discovered that male teachers were more motivated than female teachers. Fitria and colleagues (2019) The study's final conclusion is that the training process benefits teachers by increasing teachers' understanding of Classroom Action Research and fostering motivation in preparing and implementing CAR. According to Leniwati and Arafat (2017), the implementation of academic supervision occurs in three stages: planning, implementation, and evaluation. The implementation of academic supervision was met with approval from the teacher.

Ogan Komering Ulu Regency is one of 17 regencies/cities in South Sumatra Province. Ogan Komering Ulu Regency has a variety of educational institutions, both formal and informal, ranging from kindergarten to higher education. SD Negeri $11 \mathrm{OKU}$ is one of the educational institutions in the Ogan Komering Ulu district. SD Negeri 11 OKU, which has been in operation since 1963, is located at Jalan Jend. A. Yani, Kemalaraja Village, Kec. East Baturaja.

SD Negeri $11 \mathrm{OKU}$ is a school that has implemented a $10 \mathrm{M}$ school policy, which includes the following: (1). Maintain personal hygiene and tidiness (2). Before and after activities, wash your hands with clean, running water (3). Put dirt and trash in their proper places. (4). Consume nutritious and safe foods (5). Avoid smoking and consuming alcoholic beverages (6). Get in the habit of eating breakfast before your activities (7). Spitting is not permitted anywhere (8). Getting rid of disease-spreading animals (9). Maintaining fitness through regular exercise and (10). Allow enough time for rest. Furthermore, SD Negeri $11 \mathrm{OKU}$ is a pilot school in terms of managing the Waste Bank in the OKU district, earning approximately 500,000 rupiahs per month from waste that has been sorted to be given to the Waste Bank. SD Negeri 11 OKU has also achieved a number of achievements, including 2nd place at the provincial level in a healthy school competition, Ambassador of the National Level Little Doctor Competition representing South Sumatra Province, Child Friendly Referral School, 1st Place in Drum Band, and 3rd Place FL2SN at the provincial level.

Based on the initial observations made by the researchers at SD Negeri $11 \mathrm{OKU}$, the following issues were discovered. First, there was a lack of discipline on the part of the teacher, who arrived late, left class hours for no apparent reason, and assigned assignments to students that were not related to the main or main tasks. Second, teachers' pedagogical competence in delivering their students to achieve success in specific events is deteriorating. As a result, teachers' efforts to improve student achievement tend to dwindle, sometimes even in the absence of a goal, which is critical in carrying out the leader's responsibilities. The teacher's role in delivering outstanding students is still lacking; he is only a teacher who is in charge of teaching and then receives a salary/honor without caring about other aspects of education, such as providing guidance to students, developing student talents, and not carrying out remedial and enrichment programs on a regular basis. 
The role of teachers in transforming educational inputs is so important that many experts believe that there will be no change or improvement in quality in schools unless teachers' quality changes and improves. The culture of Indonesian society remains quite closed; even teacher superiors such as school principals and supervisors find it difficult to obtain data and observe the daily reality of teacher performance in front of students (Pramono, 2012).

Student achievement plummets. Good student learning achievement will have a significant impact on the nation's future life, because a nation's success in achieving its goals is determined not only by the abundance of natural resources, but also by the quality of its human resources (Hamalik, 2010). Aside from the issues raised, it is critical to conduct research on the impact of teacher education level and tenure on teacher pedagogical competence.

\section{B. Methods}

SD Negeri 11 OKU, located at Jalan Jendral. A. Yani, Kemalaraja Village, East Baturaja District, Ogan Komering Ulu Regency, conducted this research. The research method used in this study is descriptive quantitative research. This study's descriptive research is an associative causal relationship. This study's sample consisted of 50 teachers from grades 1 to 6 . In this study, data for each variable was gathered through observation and questionnaires. Because this is a quantitative study and the data obtained is also quantitative, statistical assistance is used for data analysis. In order to determine the relationship between education level and tenure, the ANOVA test with a significance level of 5\% was used.

\section{Results and Discussion}

\section{The Influence of Education Level on Teacher's Pedagogic Competence}

Based on research hypotheses, it has been determined that the level of education that a teacher possesses has a significant impact on pedagogical competence. The results of the hypothesis testing revealed a t-tabel value of 2.437 with a significance level of 0.016 . This means that the signifikansi nilai $0,0160.10$ indicates that variable tingkat pendidikan berpengaruh secara simultan terhadap variable pedagogik kompetensi, with Ha diterima dan Ho ditolak. This occurs because, over time, when a teacher learns/teaches at a higher level, he or she makes a greater contribution to the student's ability, knowledge, and professionalism.

This statement is consistent with the fact that all teachers at SD Negeri 11 OKU are qualified $\mathrm{S} 1$ and some are continuing to the Strata 2 level. Education is a critical issue in life; the progress of a nation's progress is largely determined by the progress of education in the country, because economic development, socio-culture, politics, and defense and security in a nation or state all necessitate the participation of educational efforts in every stage and process of development. Teachers must have an adequate teacher education background in order to carry out their duties and functions properly.

Other than formal education, non-formal education can support efforts to improve performance such as upgrading, workshops, seminars, workshops, deliberation, and other activities related to the teaching profession. In theory, the higher a person's educational level, the greater his abilities. Murtiningsih and Lian (2017) conclude that the level of education influences the quality of education and teaching provided by teachers, implying that the higher the level of teacher education, the better the quality of education and teaching provided. 


\section{The Effect of Working Period on Teacher's Pedagogic Competence}

According to the results of the analysis, the teacher's tenure variable has a significant influence on the teacher's pedagogic competence variable. The t-table value is 1.935 , with a level of significance of 0.043 . This means that the significance level of 0.0430 .10 indicates that the tenure variable has a concurrent effect on the pedagogical competence variable, so $\mathrm{Ha}$ is accepted and Ho is rejected. This occurs because the longer a teacher serves as an administrator, facilitator, counselor, and evaluator, the more abilities and skills he develops in his professional duties. Because education and training, as well as special education, are required to become a professional teacher, the influence is quite close.

The length of time a teacher has worked cannot be separated from the amount of experience he or she has. Because going through a relatively long working period will be able to enrich a teacher's knowledge and experience. As a result, the quality of a teacher can also be determined by this. A teacher's experience can be seen from two perspectives: externally through activities such as Teacher Working Groups and Subject Teacher Consultations, training, upgrading, seminars, and workshops, and internally through the length of time the teacher has been teaching. The length of time teachers teach, which is intended in this study as a period of work, provides insight into the development of teachers' abilities and skills in teaching so that they can improve teacher performance.

According to Murniati (2013), many teachers in educational institutions are temporarily unable to carry out their duties properly. This is said psychologically because they are still immature and inexperienced in dealing with the new tasks that have been assigned to them. As a result, teachers as educators must have sufficient knowledge and years of experience in their fields. It can be concluded that the longer a teacher works, the more teaching experience he or she will gain, so that with more teaching experience, the teacher will be able to easily and quickly solve problems encountered, particularly teaching problems that demonstrate the teacher's performance is improving.

\section{The Effect of Simultaneous Education Level and Working Period on Teacher Pedagogic Competence}

According to the results of the analysis, the education level variable and the tenure variable both have a significant influence on the teacher pedagogic competence variable. The education level variable's t-table value is 2.645 , with a significance level of 0.000 . This means that a significance level of 0.0000 .10 indicates that the education level variable has an effect on the pedagogic competence variable at the same time. The variable period of service has a t-table value of 2.192 and a significance level of 0.029 . This also implies that the significance level value is less than the t-table value. This means that the variable level of education and tenure has a significant effect on pedagogic competence, which is why $\mathrm{Ha}$ is accepted and Ho is rejected.

This occurs because teachers' educational backgrounds, as well as their length of teaching experience, contribute to their professional development. According to Nawawi, teachers with a high level of education and sufficient years of service in their fields will be able to look ahead in improving the development of the students they supervise (1981). Furthermore, an educator's working period and adequate level of education have a greater or lesser impact on their performance. 
Volume 2 (3) 2021

E-ISSN: 2723-6919 P-ISSN: 2746-0827

Furthermore, Lian et al (2020) emphasized that educators with high work maturity in their fields have the knowledge, intelligence, and experience to carry out tasks without the guidance of others. As a result, it is clear that experience is a lesson that will result in behavioral changes, increased understanding, and information enrichment. As a result, Nawawi (1981) asserts that previous experience will be very useful in supplementing a teacher's knowledge when dealing with new problems. Teachers are expected to become successful educational personnel in managing the classes they supervise over a relatively long period of time. Learning from various office experiences is extremely beneficial to teachers' professional abilities in guiding their students.

The length of time a teacher has been teaching or his teaching experience also has an impact on his teaching ability. Because the more teachers who teach, the more complete the learning materials become. Similarly, the higher the level of education, the broader the curriculum program provided and the longer the period of achievement, affecting the ability of the goals that take the program. If a teacher possesses exceptional abilities and knowledge, he is expected to be able to transfer those abilities and knowledge in order to improve the quality of education in schools in general and student achievement in particular.

\section{Conclusion}

The level of education and years of service have a partial or simultaneous influence on teacher competence. When a teacher is assessed for his pedagogical competence by a teacher friend, the highest correlation preference between education level or years of service with pedagogic competence occurs when the level of education possessed by the teacher being assessed is considered.

\section{E. Acknowledgement}

We thank to Rector Universitas PGRI Palembang, the principal of SD Negeri 11 Ogan Komering Ulu and friends who have supported us to do this project.

\section{References}

Aprida, Y., Fitria, H., \& Nurkhalis, N. (2020). Pengaruh Supervisi Kepala Sekolah Dan Motivasi Kerja Guru Terhadap Kinerja Guru [The Effect of Principal Supervision and Teacher Work Motivation on Teacher Performance]. Journal of Education Research, 1(2), 160-164.

Arino, I. (2017). Analisa Pengaruh Tingkat Pendidikan, Masa Kerja Dan Motivasi Kerja Terhadap Kinerja Perangkat Desa Di Kecamatan Kaliwiro Wonosobo [Analysis of the Effect of Education Level, Work Period and Work Motivation on Village Apparatus Performance in Kaliwiro District, Wonosobo]. Jurnal Penelitian dan Pengabdian Kepada Masyarakat Unsiq, 4(3).

Astuti, R. W., Fitria, H., \& Rohana, R. (2020). The Influence of Leadership Styles and Work Motivation on Teacher's Performance. Journal of Social Work and Science Education, 1(2), 105-114. https://doi.org/10.52690/jswse.v1i2.33 
Volume 2 (3) 2021

E-ISSN: 2723-6919 P-ISSN: 2746-0827

Fitria, H., Kristiawan, M., \& Rahmat, N. (2019). Upaya Meningkatkan Kompetensi Guru Melalui Pelatihan Penelitian Tindakan Kelas [Efforts to Improve Teacher Competence Through Classroom Action Research Training]. Abdimas Unwahas, 4(1).

Firdaus, D. (2014). Pengaruh Tingkat Pendidikan, Pelatihan, Dan Pengalaman Mengajar Terhadap Profesionalitas Guru Di Madrasah Tsanawiyah Negeri Kediri 2 [The Effect of Education Level, Training, and Teaching Experience on Teacher Professionalism at Madrasah Tsanawiyah Negeri Kediri 2]. Jurnal Didaktika Religia, 2(2).

Firman, F., Fitria, H., \& Rohana, R. (2021). The Influence of School Leadership Style and Teacher's Motivation toward Teacher's Performance. Journal of Social Work and Science Education, 2(1), 1-10. https://doi.org/10.52690/jswse.v2i1.134

Israwanti, P., Mustari, dan Mansur A. (2018). Motivasi Mengajar, Kompetensi Profesional Dan Tingkat Pendidikan Terhadap Kinerja Guru [Teaching Motivation, Professional Competence and Education Level on Teacher Performance]. Jurnal Mirai Manajemen, $3(2)$.

Krisdiana., \& Marimin. (2014). Pengaruh Tingkat Pendidikan, Fasilitas Kerja, dan Kepemimpinan Terhadap Kinerja Pegawai Kecamatan Se-Kota Tegal [The Influence of Education Level, Work Facilities, and Leadership on the Performance of District Employees in Tegal City]. Economic Education Analysis Journal EEAJ, 3(2).

Lian, B., Kristiawan, M., Primasari, D. A. G., \& Prasetyo, M. A. M. (2020). Teachers' Model In Building Students' Character. Journal of Critical Reviews, 7(14), 927-932.

Leniwati, L., \& Arafat, Y. (2017). Implementasi Supervisi Akademik Kepala Sekolah Untuk Meningkatkan Kinerja Guru [Implementation of Principal Academic Supervision to Improve Teacher Performance]. JMKSP (Jurnal Manajemen, Kepemimpinan, dan Supervisi Pendidikan), 2(1).

Muchith, M.S. (2008). Pembelajaran Kontekstual [Contextual Learning]. Semarang: Rasail Media Group.

Murniati, N. K. D. (2013). Kontribusi Kompetensi Profesional, Kompetensi Pedagogik, dan Kepuasan Kerja Terhadap Kinerja Guru PKn pada SMP Negeri se Kabupeten Tabanan [Contribution of Professional Competence, Pedagogic Competence, and Job Satisfaction to the Performance of Civics Teachers at State Junior High Schools in Tabanan Regency]. Jurnal Administrasi Pendidikan Indonesia, 4(1).

Murtiningsih, M., \& Lian, B. (2017). Proses Pengambilan Keputusan Kepala Sekolah terhadap Peningkatan Kinerja Guru SMP [The Principal's Decision Making Process on Improving the Performance of Middle School Teachers]. JMKSP (Jurnal Manajemen, Kepemimpinan, dan Supervisi Pendidikan), 2(1).

Musfah, J. (2011). Peningkatan Kompetensi Guru: Melalui Pelatihan dan. Sumber Belajar Teori dan Praktik [Teacher Competency Improvement: Through Training and. Resources for Learning Theory and Practice]. Jakarta: Kencana. 
Nawawi, H. (1981). Administrasi Pendidikan [Education administration]. Jakarta: Gunung Agung.

Pramono, H. (2012). Pengaruh Sistem Pembinaan, Sarana Prasarana Dan Pendidikan Latihan Terhadap Kompetensi Kinerja Guru Pendidikan Jasmani Sekolah Dasar Di Kota Semarang [The Influence of the Guidance System, Infrastructure and Training Education on the Performance Competence of Elementary School Physical Education Teachers in the City of Semarang]. Jurnal Penelitian Pendidikan, 29(1).

Prihatini, D., Arafat, Y., \& Mulyadi, M. (2021). The Influence of Organizational Culture and Principal Leadership Towards Teacher's Performance. Journal of Social Work and Science Education, 1(3), 204-213. https://doi.org/10.52690/jswse.v1i3.107

Riyany, E., Harapan, E., \& Tahrun, T. (2021). School Principal's Strategy in Developing Teacher's Professional Competencies to Improve Educational Quality. Journal of Social Work and Science Education, 1(3), 214-220. https://doi.org/10.52690/jswse.v1i3.10

Sadulloh, U. (2010). Pedagogik (Ilmu Mendidik) [Pedagogy (Educational Science)]. Bandung: Alfabeta.

Sudarminta, J. (2001). Citra Guru dalam Pendidikan Kegelisahan Sepanjang Jaman [The Image of Teachers in Anxiety Education Throughout the Ages]. Yogyakarta: Kanisius.

Saudagar, F., \& Idrus, A. (2009). Pengembangan Profesionalitas Guru [Teacher Professional Development]. Jakarta: Gaung Persada Press.

Triyanto., \& Handayani, R. D. (2016). Teacher Motivation Based on Gender, Tenure and Level of Education.The New Educational Review, 45(3).

Undang-Undang Nomor 14 Tahun 2005 [Law Number 14 Year 2005]

Zulfakar, Z., Lian, B., \& Fitria, H. (2020). Implementasi Supervisi Akademik Dalam Meningkatkan Kinerja Guru [Implementation of Academic Supervision in Improving Teacher Performance]. JMKSP (Jurnal Manajemen, Kepemimpinan, dan Supervisi Pendidikan), 5(2). 